\title{
PROFIL GURU DALAM KONTEKS PROFESIONAL
}

\author{
Oleh: Dra. Asnah, M.A
}

\begin{abstract}
Abstrak
Profesi pada hakekatnya adalah suatu pernyataan atau janji terbuka (to profess artinya menyatakan), yang menyatakan bahwa seseorang itu mengabdikan dirinya pada suatu jabatan atau pelayanan karena orang tersebut merasa terpanggil untuk menjabat pekerjaan itu.

Dalam konteks profesional, profil guru yang diharapkan yakni guru dengan semangat tinggi, selalu memiliki inisiatif, gigih, tidak putus asa dan tidak gampang menyerah. Guru dalam dimensi kekinian digambarkan sebagai sosok manusia yang berakhlak mulia, arif, bijaksana, berkepribadian stabil, mantap, disiplin, santun, jujur, obyektif, bertanggung jawab, menarik, mantap, empatik, berwibawa, dan patut diteladani. Selain berkarakter, guru tentu perlu memiliki pondasi yang kokoh dalam ilmu, memiliki panggilan jiwa dan keikhlasan untuk berkorban demi bangsa dan Negara.
\end{abstract}

\section{A. Pendahuluan}

Untuk memajukan pendidikan di negara kita, menurut penulis seyogianya diawali dengan memotret "profil guru" kita. Mengapa begitu? Antara lain karena peradaban bangsa merupakan cerminan karakter anak bangsa, sementara karakter manusia biasanya terbentuk secara alami melalui proses pendidikan. Kunci perbaikan pendidikan itu ada pada guru. Para gurulah yang berkewajiban membimbing peserta didik mereka menjadi insan terdidik. Untuk dapat melaksanakan tugas mulia ini secara lebih profesional, guru perlu secara terus menerus meningkatkan kompetensinya. Ini penting dan harus dilakukan, demi peningkatan profesionalitas diri guru-guru di masa mendatang. Dunia pendidikan kita kini sangat memerlukan sentuhan tangan-tangan halus dari para guru profesional ini.

\section{B. Pengertian Profesi}

Profesi berasal dari bahasa latin "Profesio" yang mempunyai dua pengertian yaitu janji/ikrar dan pekerjaan. Webstar dalam Kunandar menjelaskan bahwa profesi 
sebagai jabatan atau pekerjaan tertentu yang mensyaratkan pengetahuan dan keterampilan khusus yang diperoleh dari pendidikan akademis yang intensif. ${ }^{1}$

Everett Hughes dalam Chandler, menjelaskan bahwa istilah profesi merupakan simbol dari suatu pekerjaan dan selanjutnya menjadi pekerjaan itu sendiri. ${ }^{2}$ Sementara Liberman dalam Soetjipto dan Raflis Kosasi memaknai profesi sebagai suatu jabatan atau pekerjaan yang diperoleh melalui latihan khusus yang memadai. Demikian pula World Confederation of Organization for Teaching Profession (WCOTP) dalam buku yang sama menyatakan bahwa suatu jabatan atau pekerjaan yang biasanya memerlukan persiapan yang relatif lama dan khusus pada tingkat pendidikan tinggi yang pelaksanaannya diatur oleh kode etik tersendiri, dan menuntut tingkat kearifan atau kesadaran serta pertimbangan pribadi yang tinggi. ${ }^{3}$

Sejalan dengan pendapat di atas, Dedi Supriadi mendefinisikan profesi sebagai pekerjaan atau jabatan yang menuntut keahlian, tanggung jawab, dan kesetiaan terhadap pekerjaan tersebut. ${ }^{4}$

Makna pengertian di atas mengisyaratkan bahwa, tenaga profesional tidak sama dengan nonprofesional. Pernyataan profesional mengandung makna terbuka yang sungguh-sungguh keluar dari lubuk hatinya. Pernyataan demikian mengandung normanorma atau nilai-nilai etik. Orang yang membuat pernyataan itu yakin dan sadar bahwa pernyataan yang dibuatnya adalah baik. "Baik" dalam arti bermanfaat bagi orang banyak dan bagi dirinya sendiri. Pernyataan janji itu bukan hanya sekadar keluar dari mulutnya, tetapi merupakan ekspresi kepribadiannya dan tampak pada tingkah lakunya sehari-hari. Jika seseorang telah menganut suatu profesi tertentu, dia akan berbuat sesuai dengan janji tersebut. Suatu profesi bukan bermaksud untuk mencari keuntungan bagi dirinya sendiri, baik dalam arti ekonomis maupun dalam arti psikis, tetapi untuk pengabdian pada masyarakat.

\footnotetext{
${ }^{1}$ Kunandar, Guru Profesional: Implementasi Kurikulum Tingkat Satuan Pendidikan dan Sukses dalam Sertifikasi Guru (Jakarta: Raja Grafindo Persada, 2007), hlm. 45 hlm. 78 .

${ }^{2}$ B. J. Chandler, Education and The Teacher (New York: Dodd, Mead \& Company Inc., 1960),

${ }^{3}$ Soetjipto dan Raflis Kosasi, Profesi Keguruan (Jakarta: Rineka Cipta.2009), hlm. 76. 2008), hlm. 59

4 Dedi Supriadi, Mengangkat Citra dan Martabat Guru (Yogyakarta : Adicita Karya Nusa,
} 
Selain itu, suatu profesi erat kaitannya dengan jabatan atau pekerjaan tertentu yang menuntut keahlian, pengetahuan, dan keterampilan tertentu pula. Dalam pengertian profesi telah tersirat adanya suatu keharusan kompetensi agar profesi itu berfungsi dengan sebaik-baiknya. Dalam hal ini, pekerjaan profesional berbeda dengan pekerjaan-pekerjaan lainnya, oleh sebab mempunyai fungsi sosial, yakni pengabdian kepada masyarakat. Kompetensi sangat diperlukan untuk melaksanakan fungsi profesi. Dalam masyarakat yang kompleks seperti masyarakat modern dewasa ini, profesi menuntut kemampuan membuat keputusan yang tepat dan kemampuan membuat kebijaksanaan yang tepat. Untuk itu diperlukan banyak keterangan yang lengkap agar jangan menimbulkan kesalahan yang akan menimbulkan kerugian, baik bagi diri sendiri maupun bagi masyarakat. Kesalahan dapat menimbulkan akibat yang fatal atau malapetaka yang dahsyat. Itu sebabnya, kebijaksanaan, pembuatan keputusan, perencanaan, dan penanganan harus ditangani oleh para ahlinya, yang memiliki kompetensi profesional dalam bidangnya.

Dengan demikian dapat dipahami bahwa profesi guru adalah suatu jabatan yang mempunyai kekhususan. Kekhususan itu memerlukan kelengkapan mengajar dan/atau keterampilan yang menggambarkan bahwa seseorang melakukan tugas mengajar, yaitu membimbing manusia.

Robert Richey mengemukakan ciri-ciri guru sebagai suatu profesi, yaitu:

1. Adanya komitmen dari para guru bahwa jabatan itu mengharuskan pengikutnya menjunjung tinggi martabat kemanusiaan lebih dari pada mencari keuntungan.

2. Suatu profesi mensyaratkan orangnya mengikuti persiapan professional dalam jangka waktu tertentu.

3. Harus selalu menambah pengetahuan agar terus menerus bertumbuh dalam jabatannya.

4. Memiliki kode etik jabatan.

5. Memiliki kemampuan intelektual untuk menjawab permasalahan yang dihadapi.

6. Selalu ingin belajar terus menerus mengenai bidang keahlian yang ditekuni.

7. Menjadi anggota dari suatu organisasi profesi. 
8. Jabatan itu dipandang sebagai suatu karir hidup. ${ }^{5}$

Berdasarkan pandangan di atas dapat dikatakan bahwa hakekat suatu profesi adalah lebih mengutamakan tugasnya sebagai suatu layanan sosial yang dilandasi dengan sejumlah pengetahuan yang sistematis dan tanggung jawab moral yang tinggi.

\section{Guru Profesional}

Profesional sering diartikan sebagai suatu keterampilan teknis yang dimiliki seseorang. Secara luas profesional mengandung makna ahli, memiliki otonomi dan tanggung jawab (intelektual dan moral), dan memiliki rasa kesejawatan.

\section{Ahli.}

Seorang guru dituntut agar ahli dalam bidang yang diajarkan dan ahli dalam cara mengajarkan bidang studi tersebut juga ahli dalam tugas-tugas mendidik lainnya. Kunandar mengemukakan bahwa suatu pekerjaan profesional memerlukan persyaratan khusus, di antaranya: a) menuntut adanya keterampilan berdasarkan konsep dan teori ilmu pengetahuan yang mendalam, b) menekankan pada suatu keahlian dalam bidang tertentu sesuai dengan bidang profesinya. ${ }^{6}$

Mengajar adalah sarana untuk mendidik, sehingga mengajar dapat dikatakan sebagai pengetahuan (teaching is a knowledge), juga mengajar adalah keterampilan (teaching is a skill), dan mengajar juga suatu seni (teaching is an art). Keterampilan mengajar merupakan kompetensi profesional yang cukup kompleks, sebagai integrasi dari berbagai kompetensi guru secara utuh dan menyeluruh. ${ }^{7}$ Dengan demikian keahlian guru mengajar harus dilihat dari berbagai sisi, sehingga dia dapat menyentuh inti kemanusiaan peserta didik melalui pembelajaran yang dilaksanakannya.

\section{Otonomi dan Tanggung jawab} hlm. 59.

5 Robert Richey, Planning for Teaching Instruction to Education (t.t.p: Mc. Graw Hill, 2002),

${ }^{6}$ Kunandar, Op.Cit., hlm. 47.

${ }^{7}$ E. Mulyasa, Menjadi Guru Profesional Menciptakan Pembelajaran Kreatif dan Menyenangkan (Bandung: Remaja Rosdakarya, 2006), hlm. 69. 
Guru yang professional di samping ahli dalam bidang mengajar dan mendidik, ia juga memiliki otonomi dan tanggung jawab. Otonomi adalah suatu sikap yang profesional yang disebut mandiri. Karena tugas mengajar dilakukan secara mandiri, maka guru harus bertanggungjawab secara intelektual dan juga moral. Artinya apa yang disampaikan/diajarkan harus dapat dipertanggungjawabkan secara ilmiah. Sementara tanggung jawab moral berarti guru harus bertanggung jawab kepada dirinya sendiri, terhadap siswa, orang tua, lingkungan sekitar, masyarakat, bangsa dan negara, dan akhirnya terhadap Tuhan Maha Pencipta.

\section{Memiliki Rasa Kesejawatan}

Salah satu tugas dari organisasi profesi ialah menciptakan rasa kesejawatan sehingga ada rasa aman dan perlindungan jabatan. Semangat korps dikembangkan agar harkat dan martabat guru dijunjung tinggi, baik oleh korps guru sendiri maupun masyarakat pada umumnya.

Guru profesional adalah guru yang mau mengabdikan keseluruhan hidupnya dalam mendidik dan berusaha mencapai tujuan pendidikan dengan kompetensi profesionalnya.

Kompetensi profesional guru dapat diartikan sebagai kemampuan seorang guru dalam melaksanakan tugas profesi keguruan dengan penuh tanggung jawab dan dedikasi tinggi dengan sarana penunjang berupa bekal pengetahuan yang dimilikinya. Kompetensi merupakan perilaku yang rasional untuk mencapai tujuan yang dipersyaratkan sesuai dengan kondisi yang dipersyaratkan pula. Kompetensi sangat diperlukan untuk mengembangkan kualitas dan aktivitas pendidik.

Guru sebagai pendidik merupakan faktor penentu keberhasilan pendidikan di sekolah. Tugas guru yang utama adalah memberikan pengetahuan (cognitive), sikap/nilai (affective), dan keterampilan (psychometer) kepada peserta didik. Guru sebagai ujung tombak pendidikan memegang peranan penting keberhasilan pendidikan di Indonesia, di samping faktor-faktor pendukung lainya. 
Seiring dengan perkembangan dan perubahan peradaban dewasa ini guru sebagai orang yang patut digugu dan ditiru mengalamai degradasi mental untuk digugu dan ditiru. Guru sebagai pihak yang bertanggungjawab dan mempertanggungjawabkan tugasnya justru menjadi pihak yang sering kali mengabaikan tanggungjawabnya. Hal ini bisa dilihat dari kehadiran, rasa memiliki, dan kewajiban untuk menjadikan peserta didik menguasai kompetensi hilang, yang ada bahwa guru hanya sekedar menggugurkan kewajiban.

Hal-hal yang terkait dengan tanggungjawab terhadap upaya mencerdaskan bangsa terabaikan, yang ada dibenak guru bagaimana menghabiskan waktu kehadiran di sekolah untuk sekedar menggugurkan kewajiban mengajarnya. Sungguh ironis ketika kita semua tahu bahwa anak-anak bangsa ini terpuruk dan keterpurukan itu hanya bisa diangkat dengan peningkatan kemampuan dan kompetensi yang dimilikinya, guru sebagai pihak yang seharusnya berada di barisan terdepan justru berada di barisan belakang dengan tidak peduli lagi terhadap tanggungjawabnya.

\section{Profil Guru dalam Konteks Profesional}

Berbicara tentang profil guru dalam konteks profesional berarti berbicara tentang profil kompetensi guru. Profil kompetensi ialah penampilan guru dalam melakukan tugasnya yang memenuhi syarat sesuai dengan kriteria kemampuan yang dipersyaratkan. Profil ini selalu mengacu pada aspek kompetensi yang dimiliki seorang guru profesional.

Seorang guru profesional bekerja berdasarkan kata hati, uraian tugas (job description) dan etika. Ketiga hal itu, hari demi hari guru lakukan di sekolah sebagai pendidik di ruang guru saat bertemu dan berbicara dengan sesama guru dan di dalam dan di luar sekolah saat bertemu dengan orang tua siswa. Profil guru saat ini kerap menjadi sorotan karena semua pihak, hari ini pun masih membandingkan profil guru sekarang dengan profil guru di masa lalu. Di masa lalu seorang guru dikenal karena keikhlasan dan kemauan memberikan yang terbaik dalam hidupnya bagi siswanya. Jika 
dibandingkan dengan keadaan sekarang akan ada perbedaan sedikit banyak, apalagi jika disangkutpautkan dengan kesejahteraan.

Sementara kompetensi adalah variasi kuantitatif dan kualitatif perangkat kompetensi yang dimiliki oleh korps pendidik yang dibutuhkan dalam melaksanakan tugas kependidikan. ${ }^{8}$

Glickman mengemukakan dua kemampuan dasar yang harus dimiliki oleh guru yaitu kemampuan berpikir abstrak dan tingkat komitmen. ${ }^{9}$ Idealnya setiap guru harus memiliki kompetensi tingkat berpikir abstrak, kreatif dan imaginatif. Hasil penelitian yang telah dilakukan Harvey, Hunt dan Joyce dalam Glickman membuktikan bahwa guru yang tingkat pengembangan kognitifnya tinggi akan berpikir lebih abstrak, imaginatif, kreatif dan demokratis. Mereka lebih fleksibel dalam melakukan tugasnya. ${ }^{10}$

Glassberg dalam Glickman menyimpulkan hasil penelitiannya bahwa guru-guru yang tingkat berpikir abstraknya tinggi memiliki daya adaptasi dan gaya mengajar yang lebih fleksibel. Mereka lebih supel serta mampu menggunakan berbagai model mengajar dan menciptakan berbagai variasi mengajar yang menyenangkan. ${ }^{11}$

Seorang guru yang tidak memiliki kemampuan berpikir abstrak yang tinggi hanya mampu menemukan satu alternatif pemecahan masalah saja. Sementara masalah yang dihadapi guru harus dapat di atasi dengan berbagai alternatif pemecahan masalah.

Selain tingkat berpikir abstrak guru juga memiliki tingkat komitmen. Komitmen adalah kecenderungan dalam diri seseorang untuk merasa terlibat aktif dengan penuh rasa tanggung jawab. Dalam komitmen tercakup arti usaha dan dorongan serta waktu yang cukup banyak.

Seorang guru yang punya komitmen tinggi akan memiliki kepedulian terhadap tugas, kebutuhan siswa, dan teman sejawat. Francis Fuller, memberi kesimpulan bahwa setiap saat para guru harus meningkatkan komitmen dan kepedulian terhadap setiap

${ }^{8}$ Doddy A. Tisnaamidjaja, Pola Pembaharuan Sistem Pendidikan Tenaga Kependidikan di Indonesia (Jakarta: Direktorat Jendral Pendidikan Tinggi Depdikbud, 2009), hlm. 77.

9 Carl AD. Glickman, Development Supervision: Alternative Practice for Helping Teacher Improve Instruction (Virginia: ASCD, 1981), hlm. 121.

${ }^{10}$ Ibid.

11 Ibid., hlm. 123. 
perubahan tugas profesinya. ${ }^{12}$ Komitmen dan kepedulian dapat timbul bila ada rasa cinta terhadap tugas dan panggilan hati nurani terhadap tugas guru/mengajar tersebut.

Dalam pola pemahaman sistem tenaga pendidik di Indonesia ada tiga dimensi umum kompetensi yang saling mendukung untuk membentuk profil kompetensi profesional tenaga pendidik, yaitu: 1) Kompetensi Personal, 2) Kompetensi Sosial, 3) Kompetensi Profesional, dan 4) Kompetensi pedagogik.

Kompetensi personal adalah seperangkat kemampuan dan karakteristik personal yang mencerminkan realitas sikap dan perilaku guru dalam melaksanakan tugastugasnya dalam kehidupan sehari-hari. Kompetensi kepribadian ini melahirkan profil guru di antaranya, sabar, tenang, tanggung jawab, demokratis, ikhlas, cerdas, menghormati orang lain, stabil, ramah, tegas, berani, kreatif, inisiatif, dll.

Untuk meneguhkan kesuksesan kinerja pendidik sebagai guru profesional dan merupakan jabatan strategis dalam membangun masyarakat, Mohamad Surya menekankan perlunya seorang guru memiliki kepribadian efektif. Kepribadian efektif seorang guru adalah kepribadian berkualitas yang mampu berinteraksi dengan lingkungan pendidikan yang sebaik-baiknya agar kebutuhan dan tujuan pendidikan dapat tercapai secara efektif. ${ }^{13}$

Kompetensi profesional adalah seperangkat kemampuan dan keterampilan terhadap penguasaan materi pelajaran secara mendalam, utuh dan komprehensif. Guru yang memiliki kompetensi profesional tidak cukup hanya memiliki penguasaan materi secara formal (dalam buku panduan) tetapi juga harus memiliki kemampuan terhadap materi ilmu lain yang memiliki keterkaitan dengan pokok bahasan mata pelajaran tertentu.

Kompetensi Pedagogik Guru yaitu kemampuan yang harus dimiliki guru berkenaan dengan karakteristik siswa dilihat dari berbagai aspek seperti moral, emosional, dan intelektual. Hal tersebut berimplikasi bahwa seorang guru harus mampu menguasai

\footnotetext{
${ }^{12}$ Francis Fuller, "Concern of Teacher: A Development Conceptualization", American Research Journal, 6 March 1979.

${ }^{13}$ Mohamad Surya, Membangun Profesionalisme Guru (Jakarta: Bina Aksara, 2005), hlm. 290292
} 
teori belajar dan prinsip-prinsip belajar, karena siswa memiliki karakter, sifat, dan interest yang berbeda. Berkenaan dengan pelaksanaan kurikulum, seorang guru harus mampu mengembangkan kurikulum tingkat satuan pendidikan masing-masing dan disesuaikan dengan kebutuhan lokal. Guru harus mampu mengoptimalkan potensi peserta didik untuk mengaktualisasikan kemampuannya di kelas, dan harus mampu melakukan kegiatan penilaian terhadap kegiatan pembelajaran yang telah dilakukan. kompetensi guru.

Kemampuan yang harus dimiliki guru berkenaan dengan aspek-aspek pedagogik, yaitu: penguasaan terhadap karakteristik peserta didik dari aspek fisik, moral, sosial, kultural, emosional dan intelektual. Penguasaan terhadap teori belajar dan prinsip-prinsip pembelajaran yang mendidik. Mampu mengembangkan kurikulum yang terkait dengan bidang pengembangan yang diampu. Menyelenggarakan kegiatan pengembangan yang mendidik. Memanfaatkan teknologi informasi dan komunikasi untuk kepentingan penyelenggaraan kegiatan pengembangan yang mendidik. Memfasilitasi pengembangan potensi peserta didik untuk mengaktualisasikan berbagai potensi yang dimiliki. Berkomunikasi secara efektif, empatik, dan santun dengan peserta didik. Melakukan penilaian dan evaluasi proses dan hasil belajar, memanfaatkan hasil penilaian dan evaluasi untuk kepentingan pembelajaran.

Berdasarkan keempat dimensi tersebut, maka ada empat aspek yang harus dikaji dari kompetensi guru yaitu aspek kepribadian/sifat-sifat guru, aspek perilaku sosial, aspek keahlian/penguasaan bidang ilmu dan aspek kemampuan mendidik dan mengajar guru.

Hasil penelitian Witty dalam Sahertian, sejumlah 14.000 siswa mulai dari tingkat SD sampai SLTA, telah memberikan pendapat mengenai sifat-sifat yang disukai dan yang tidak disukai dari seorang guru.

Sifat-sifat guru yang disukai antara lain:

1. Mau bekerjasama dan demokratis;

2. Ramah tamah dan suka mendengarkan orang lain;

3. Sabar;

4. Luas pandangan dan menaruh perhatian pada orang lain; 
5. Penampilan pribadi yang menyenangkan dan sopan santun;

6. Jujur;

7. Suka humor;

8. Kemampuan kerja yang baik dan konsisten;

9. Menaruh perhatian pada masalah yang dihadapi siswa;

10. Fleksibel dalam cara mengajar;

11. Bisa menggunakan pujian dan mau memperbaiki;

12. Pandai sekali dalam mengajar pada bidang studi. ${ }^{14}$

Sementara sifat-sifat guru yang tidak disenangi mereka, antara lain:

1. Temperamen yang buruk;

2. Tidak beres dan suka mencari popularitas murahan;

3. Tidak pernah menolong siswa;

4. Kurang rasional dan kurang realistis;

5. Suka bicara yang tidak benar;

6. Terlalu kasar dan kejam;

7. Penampilan yang kurang menarik;

8. Kurang fleksibel;

9. Cenderung untuk berbohong;

10. Suka menjatuhkan siswa;

11. Terlalu berlebih-lebihan;

12. Kurang humor. ${ }^{15}$

Selanjutnya mengenai perilaku sosial guru, dapat dilihat dari:

1. Penampilan hidup/citra guru di tengah masyarakat;

2. Bekerjasama dan berhubungan dengan rekan sejawat;

3. Bekerjasama dengan siswa baik dalam kelas maupun di luar kelas;

4. Menciptakan dan memelihara kehidupan yang normal dalam keluarga;

Selanjutnya keahlian/penguasaan ilmu yang diajarkan guru terkait dengan bidang keahliannya, dapat dilihat antara lain:

1. Menguasai substansi keilmuan yang terkait dengan bidang studi;

2. Memahami materi ajar yang ada dalam kurikulum;

3. Memahami hubungan konsep antar mata pelajaran;

4. Menguasai struktur dan metode keilmuan. ${ }^{16}$

${ }^{14}$ Piet A Sahertian, Profil Pendidik Profesional (Yogyakarta: Andi Offset, 1994), hlm. 57.

${ }^{15}$ Ibid., hlm. 57-58. 
Sedangkan kemampuan guru terkait dengan tugas mengajarnya, dapat dilihat antara lain:

1. Memahami peserta didik secara mendalam;

2. Merancang pembelajaran;

3. Melaksanakan pembelajaran;

4. Menguasai keterampilan mengajar;

5. Menilai hasil dan proses pembelajaran;

6. Melaksanakan bimbingan dan penyuluhan. ${ }^{17}$

Dari uraian-uraian di atas dapat dikatakan bahwa guru yang baik yaitu guru yang mempunyai sifat/atribut-atribut moral yang baik. Selanjutnya seorang guru dikatakan berhasil bila dalam mengajar ia dapat menunjukkan kemampuannya baik dari segi keilmuan maupun pengelolaan pembelajarannya, sehingga tujuan yang telah ditentukan dapat dicapai oleh peserta didik. Kemudian guru dikatakan efektif bila ia dapat mendayagunakan waktu dan tenaga yang sedikit tetapi dapat mencapai hasil yang maksimal.

Dedi Supriadi menawarkan lima hal profil guru yang diharapkan agar menjadi guru profesional. Kelima hal tersebut adalah:

1. Mempunyai komitmen pada siswa dan proses belajarnya. Ini berarti bahwa komitmen tertinggi guru adalah kepada kepentingan siswanya.

2. Menguasai secara mendalam bahan/mata pelajaran yang diajarkannya serta cara mengajarkannya kepada para siswa.

3. Bertanggungjawab memantau hasil belajar siswa melalui berbagai teknik evaluasi, mulai cara pengamatan dalam perilaku siswa sampai tes hasil belajar.

4. Mampu berpikir sistematis tentang apa yang dilakukannya, dan belajar dari pengalamannya. Artinya, harus selalu ada waktu bagi guru guna mengadakan refleksi dan koreksi terhadap apa yang telah dilakukannya. Untuk bisa belajar dari

\footnotetext{
${ }^{16}$ Kunandar, Op.Cit., hlm. 77.

${ }^{17}$ Muhammad Uzer Usman, Menjadi Guru Profesional (Bandung: Remaja Rosdakarya, 2005), hlm.
} 
pengalaman, ia harus tahu mana yang benar dan salah, serta baik buruk dampaknya pada proses belajar siswa.

5. Seyogyanya guru merupakan bagian dari masyarakat belajar dalam lingkungan profesinya. $^{18}$

Guru profesional adalah guru yang memiliki keahlian, tanggung jawab, dan rasa kesejawatan yang didukung oleh etika profesi yang kuat. Untuk itu ia harus memiliki kualifikasi kompetensi yang memadai yaitu; kompetensi intelektual, sosial, spiritual, pribadi dan moral. ${ }^{19}$ Selanjutnya Sudarwan Danim dalam buku yang lain, menggagaskan profil guru professional abad 21 sebagai berikut:

1. Memiliki kepribadian yang matang dan berkembang. Ini berarti bahwa seorang guru profesional adalah pribadi-pribadi unggul terpilih.

2. Menguasai ilmu pengetahuan dan teknologi yang kuat. Melalui dua hal ini seorang guru profesional akan menginspirasi anak didiknya dengan ilmu dan teknologi. Guru profesional semestinya seorang 'ilmuwan' yang dibentuk menjadi pendidik.

3. Menguasai keterampilan untuk membangkitkan minat dan potensi peserta didik. Oleh karena itu seorang guru profesional harus menguasai keterampilan metodologis membelajarkan siswa. Karakteristik ini yang membedakan profesi guru dari profesi lainnya. Jika karakteristik ini tidak secara sungguh-sungguh dikuasai guru, maka siapa saja dapat menjadi guru seperti yang terjadi sekarang ini. Akibat lebih lanjut dari ini adalah profesi guru akan kehilangan 'bargaining position'.

4. Pengembangan profesi yang berkesinambungan. Profesi guru adalah profesi mendidik. Seperti halnya ilmu mendidik yang senantiasa berkembang, maka profil guru profesional adalah guru yang terus menerus mengembangkan kompetensi dirinya. Pengembangan kompetensi ini dapat dilakukan secara institusional (LPTK), dalam praktik pendidikan, atau secara individual. ${ }^{20}$

\footnotetext{
18 Dedi Supriadi, Op.Cit., hlm. 98.

${ }^{19}$ Sudarwan Danim, Profesionalisasi dan Kode Etik Guru (Bandung: Alfabeta, 2010), hlm. 28.

20 Sudarwan Danim, Pengembangan Profesi Guru: Dari Induksi ke Profesional Madani, (Jakarta: Media Perhalindo, 2011), hlm. 101.
} 
Selain itu, profil guru dalam konteks profesional harus memiliki ciri-ciri atau karakteristik sebagai berikut:

1. Guru profesional harus memiliki landasan pengetahuan yang kuat.

2. Guru profesional harus berdasarkan kompetensi individual.

3. Guru profesional harus melalui sistem seleksi dan sertifikasi.

4. Guru profesional harus mampu bekerjasama dan berkompetisi yang sehat dengan sejawat.

5. Guru profesional harus mempunyai kesadaran profesional yang tinggi.

6. Guru profesional harus memahami dan memiliki prinsip-prinsip etik (kode etik).

7. Guru profesional harus patuh terhadap sistem sanksi profesi.

8. Guru profesional mempunyai militansi individual.

9. Guru profesional harus memiliki organisasi profesi. ${ }^{21}$

Dengan demikian dapat disimpulkan bahwa profil guru dalam konteks profesional tidak bisa datang dari mana saja tanpa melalui sistem pendidikan profesi dan seleksi yang baik, sehingga memiliki berbagai kompetensi yang telah dinyatakan di atas.

\section{E. Penutup}

Profil Guru dalam konteks profesional adalah seorang guru yang tidak hanya mengajar tapi juga mampu mendidik dan membentuk pribadi peserta didik yang baik. Memiliki akhlak terpuji, menjunjung tinggi kejujuran, dan bertanggungjawab terhadap tupoksinya, serta ikhlas menjalankan kewajiban. Menyayangi anak dengan sepenuh hatinya, mampu bekerjasama dengan teman sejawat, dan berwawasan luas, memahami dan mengerti segala tingkah laku siswa memberikan kenyamanan bagi peserta didiknya sehingga ilmu yang diberikan dapat diserap dan bermanfaat bagi peserta didiknya.

${ }^{21}$ Oemar Hamalik, Pendidikan Guru Berdasarkan Pendekatan Kompetensi (Jakarta: Bumi Aksara, 2004), hlm. 84. 
Memberi teladan yang baik loyal terhadap tugas-tugas yang diberikan serta dilaksanakan dengan penuh dedikasi tinggi.

Selain itu, profil guru juga harus memiliki keterampilan dasar pembelajaran, kualifikasi keilmuan juga optimal, performance di dalam kelas maupun luar kelas tidak diragukan. Tentunya sebagai guru bangga dengan profesinya, dan akan tetap setia menjunjung tinggi kode etik profesinya.

\section{DAFTAR LITERATUR}

B. J. Chandler. Education and The Teacher. New York: Dodd, Mead \& Company Inc., 1960.

Carl AD. Glickman. Development Supervision: Alternative Practice for Helping Teacher Improve Instruction. Virginia: ASCD, 2001.

Dedi Supriadi. Mengangkat Citra dan Martabat Guru. Yogyakarta: Adicita Karya Nusa, 2008.

Doddy A. Tisnaamidjaja. Pola Pembaharuan Sistem Pendidikan Tenaga Kependidikan di Indonesia. Jakarta: Direktorat Jendral Pendidikan Tinggi Depdikbud, 2009.

E. Mulyasa. Menjadi Guru Profesional Menciptakan Pembelajaran Kreatif dan Menyenangkan. Bandung: Remaja Rosdakarya, 2006.

Francis Fuller. "Concern of Teacher: A Development Conceptualization", American Research Journal, 6 March 1979.

Kunandar. Guru Profesional: Implementasi Kurikulum Tingkat Satuan Pendidikan dan Sukses dalam Sertifikasi Guru. Jakarta: Raja Grafindo Persada, 2007.

Mohamad Surya. Membangun Profesionalisme Guru. Jakarta: Bina Aksara, 2005.

Muhammad Uzer Usman. Menjadi Guru Profesional. Bandung: Remaja Rosdakarya, 2005.

Oemar Hamalik. Pendidikan Guru Berdasarkan Pendekatan Kompetensi. Jakarta: Bumi Aksara, 2004.

Piet A Sahertian. Profil Pendidik Profesional. Yogyakarta: Andi Offset, 1994.

Robert Richey. Planning for Teaching Instruction to Education. t.t.p: Mc. Graw Hill, 2002.

Soetjipto dan Raflis Kosasi. Profesi Keguruan. Jakarta: Rineka Cipta, 2009. 
Sudarwan Danim. Pengembangan Profesi Guru: Dari Induksi ke Profesional Madani. Jakarta: Media Perhalindo, 2011.

. Profesionalisasi dan Kode Etik Guru. Bandung: Alfabeta, 2010. 